Brit. J. industr. Med., 1963, 20, 35.

\title{
URINARY DELTA AMINO-LAEVULINIC ACID AND PORPHOBILINOGEN IN LEAD-EXPOSED WORKERS
}

\author{
BY \\ A. J. de KRETSER and H. A. WALDRON \\ From the Medical Department, Vauxhall Motors Ltd., Luton
}

(RECEIVED FOR PUBLICATION SEPTEMBER 20, 1961)

\begin{abstract}
Of 100 workers exposed to lead in varying degrees, 34 had a urinary delta amino-laevulinic acid (ALA) concentration of above $0.6 \mathrm{mg} . / 100 \mathrm{ml}$. and a further 35 had an ALA concentration of between $0.3 \mathrm{mg}$. and $0.6 \mathrm{mg} . / 100 \mathrm{ml}$. In only 20 of the workers was the urinary porphobilinogen concentration above $0.1 \mathrm{mg}$. $/ 100 \mathrm{ml}$., two of these being above $0.2 \mathrm{mg} . / 100 \mathrm{ml}$.

No significant correlation was found between the urinary concentration of ALA and coproporphyrin, nor was there correlation between the ALA and urinary lead levels, in fact the highest level of ALA was associated with a urinary lead of less than $200 \mu \mathrm{g}$./litre. A raised urinary lead was always associated with a raised ALA.
\end{abstract}

In 1956, Mauzerall and Granick described a new method for the estimation of urinary delta aminolaevulinic acid and porphobilinogen (ALA and PBG), using preliminary separation onto ionexchange resins. Since then, various authors, e.g. Haeger (1957), Haeger-Aronsen (1960), Griggs and Harris (1958), Tanabe (1959) and S. Schwartz (1961, personal communication), have shown that the urinary excretion of ALA is consistently raised in cases of clinical plumbism and in workers exposed to lead. Tishkoff, Granville, Rosen, and Dameshek (1958) described three cases of clinical plumbism, two of whom showed a raised ALA, although the third was normal until treatment with versene was begun, when the level increased.

The evidence as to whether the PBG is similarly raised is much less clear. Waldenström (1937), before the use of ion-exchange resins, was unable to show any increase in the excretion of PBG in lead workers. Watson, Hawkinson, and Bossenmaier (1953) and Bashour $(1954,1955)$, using a similar technique to Waldenström, the basis of which was the demonstration of a positive Ehrlich reaction in freshly voided urine and subsequent identification of the condensation product, found that PBG levels were slightly raised.

Tanabe (1959) used the more specific method of Mauzerall and Granick and found an elevation of the urinary PBG concentration in cases of plumbism.
Tishkoff et al. (1958), in three cases of lead poisoning, found that in one there was a transient elevation of the PBG (the same case in which there was a normal ALA), although the PBG in the other two cases was normal.

Griggs and Harris (1958) in their investigations found that the excretion of PBG was consistently normal as did Haeger-Aronsen (1960), although in the same paper, she reported that the PGB was invariably raised in lead-poisoned rabbits. $S$. Schwartz (1961, personal communication) states that in persons who are exposed to lead, "Elevated PBG levels are sometimes found, but these are not very marked".

In view of these conflicting reports it was decided to investigate the urinary ALA and PBG levels in 100 workers exposed to lead to determine whether (a) there was any increase in the excretion of either of these metabolites and (b) whether there was any correlation between the excretion of these substances and coproporphyrin as suggested by Tanabe (1959).

\section{Methods}

The following investigations were performed on all subjects.

Haemoglobin was determined as cyanmethaemoglobin using an E.E.L. colorimeter, taking 14.6 g. as $100 \%$ haemoglobin.

Urinary ALA and PBG was estimated by the method 
of Mauzerall and Granick (1956) using preliminary separation onto Dowex ion-exchange resins and subsequent elution of the ALA and PBG and reaction with a modified Ehrlich reagent.

Urinary lead and coproporphyrin concentration and punctate basophil counts were estimated by the methods described below. The urinary lead estimations and punctate basophil counts were performed by the techniques described by King and Thompson (1961).

Urinary Lead.-To $25 \mathrm{ml}$. urine in a $250 \mathrm{ml}$. "pyrex" beaker was added $20 \mathrm{ml}$. redistilled concentrated nitric acid and $5 \mathrm{ml} .72 \%$ perchloric acid. This was heated on a hot plate at about $280^{\circ} \mathrm{C}$. until just dry, and concentrated nitric acid was added dropwise as necessary towards the end of drying to remove any brown discoloration. The beaker was removed from the hot plate and allowed to cool.

To the residue $100 \mathrm{ml}$. de-ionized water was added, heated to obtain solution, cooled, and transferred to a separating funnel. Then $5 \mathrm{ml}$. concentrated (880) ammonium hydroxide, $3 \mathrm{ml}$. $50 \%$ ammonium citrate solution, and $10 \mathrm{ml}$. of a buffer solution (consisting of $3 \mathrm{ml}$. $50 \%$ ammonium citrate, $10 \mathrm{ml}$. concentrated ammonium hydroxide $(880)$ and $30 \mathrm{ml} .10 \%$ potassium cyanide solution, made to one litre with de-ionized water) were added.

The sample was extracted with $20 \mathrm{ml}$. chloroform and $0.2 \mathrm{ml}$. dithizone $(0.1 \%$ in chloroform), and the extract washed three times with $20 \mathrm{ml}$. of a wash solution consisting of $10 \mathrm{ml} .10 \%$ potassium cyanide and $10 \mathrm{ml}$. (880) ammonium hydroxide made to one litre with de-ionized water. A $12.5 \mathrm{~cm}$. filter paper was added to absorb residual water. The absorption of the chloroform/lead dithizonate solution was measured at $525 \mathrm{~m} \mu$ and converted to lead concentration in urine from a prepared calibration curve. The chloroform may be prepared for use again by the method of Biddle (1936).

Punctate Basophil Count.-A thin blood smear was made on a slide of 0.8 to $1.0 \mathrm{~mm}$. thickness, fixed for about one minute in methyl alcohol, and allowed to dry. It was stained for $30 \mathrm{sec}$. in Sellars stain $(1 \mathrm{~g}$. methylene blue, $6 \mathrm{~g}$. sodium bicarbonate in $100 \mathrm{ml}$. de-ionized water), and washed in tap water until the slide was a sea-green colour.

Using a dark ground condenser and an Ehrlich eyepiece set to a $6 \mathrm{~mm}$. square, the punctate cells in 10 consecutive fields were counted. (Although in counting, the punctate cells are classified as large, medium, small, very fine, or polychrome according to the size of the intracellular structure, this differentiation is for further reference on an individual case, and normally only the total count is given.)

The eyepiece was closed to a $2 \mathrm{~mm}$. square and the red blood cells in this square were enumerated. Both counts were repeated five times on different parts of the slide to give a punctate count of 50 large fields and a red blood cell count of five small ones, and the number of punctates recorded as per million red blood cells.

Urinary Coproporphyrin (semi-quantitative). $-5 \mathrm{ml}$. of urine shielded from light before use was placed in a test-tube and to it was added $1 \mathrm{ml}$. glacial acetic acid and $3 \mathrm{ml}$. ether. The tube was then corked and inverted twice and the ether layer allowed to separate before adding $1 \mathrm{ml}$. freshly prepared $0.005 \%$ iodine solution (prepared from a stock solution of $1 \mathrm{~g}$. resublimed iodine in $100 \mathrm{ml}$. ethanol and distilled water to $200 \mathrm{ml}$. stored in a refrigerator). The test-tube was again stoppered, inverted twice, and allowed to stand overnight before reading under ultraviolet light.

The urines were graded according to the degree of red fluorescence in the ether layer as,,,,,- \pm++++++ , +++ .

Quantitative Coproporphyrin.-An accurately measured volume of urine (about $25 \mathrm{ml}$.) was taken into a separating funnel of $250 \mathrm{ml}$. capacity and acidified with about onetenth its volume of glacial acetic acid. The porphyrin was extracted with $20 \mathrm{ml}$. portions of ether until there was no further fluorescence in the ether layer under ultraviolet light. The pooled ether extracts were washed with de-ionized water and then with $0.005 \%$ iodine $(V / 2)$. The iodine oxidized the porphyrinogens to the fluorescing porphyrin and was prepared freshly by diluting $1 \mathrm{ml}$. of stock solution, consisting of $1 \mathrm{~g}$. resublimed iodine in $100 \mathrm{ml}$. ethanol, to $200 \mathrm{ml}$. with de-ionized water. The stock solution was kept in the dark at $5^{\circ} \mathrm{C}$.

The iodine phase was separated and the ether again washed with a little de-ionized water. The porphyrins were now extracted from the ether with successive portions of $5 \% \mathrm{HCl}(120 \mathrm{ml}$. concentrated acid diluted to one litre with de-ionized water) until the acid phase no longer showed red fluorescence under ultraviolet light.

The combined acid washings were made neutral to Congo red with saturated sodium acetate and the porphyrins re-extracted into ether, after which the ether phase was again washed with water.

Coproporphyrin was now extracted into $0 \cdot 1 \mathrm{~N} \mathrm{HCl}$ until no further fluorescence was observed in the acid layer.

The concentration of the coproporphyrin was determined spectrophotometrically, the peak reading being at about $401 \mathrm{~m} \mu$. There are impurities that interfere with the spectral absorption in the Soret band region, and correction divisors have therefore been given (Rimington and Sveinsson, 1950; Holti, Rimington, Tate, and Thomas, 1958; With, 1955; Zondag and van Kampen, 1956; and, more recently, Rimington, 1960) from which formulae have been devised for accurate analysis.

The formula that we used is that of Rimington (1958).

If $V=$ volume of urine taken,

$v \quad=$ volume of acid extract

D430 = optical density at $430 \mathrm{~m} \mu$,

D380 = optical density at $380 \mathrm{~m} \mu$,

Dmax = optical density at peak of Soret band, then the concentration of coproporphyrin $(\mathrm{Cp})$ is given by the formula,

$2 \mathrm{Dmax}-(\mathrm{D} 430+\mathrm{D} 380) \times 730 \times \frac{v}{V}=\mu \mathrm{g} . \mathrm{Cp} /$ litre.

\section{Results}

Of the 100 workers, 34 showed an ALA excretion 


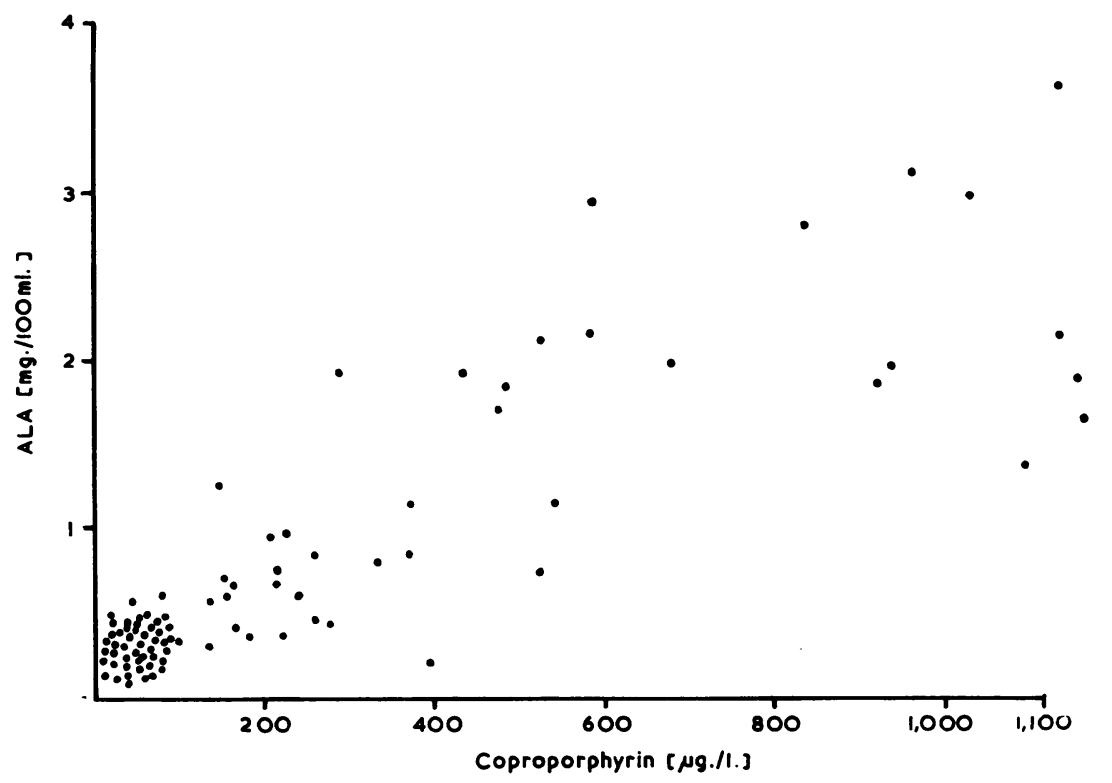

FIG. 1.-Urinary levels of ALA plotted against those of coproporphyrin.

above $0.6 \mathrm{mg} . / 100 \mathrm{ml}$., the upper limit of the range of normal quoted by Haeger-Aronsen (1960), and in a further 35 the level was between $0.3 \mathrm{mg} . / 100 \mathrm{ml}$. [the mean of the normal given by Haeger (1958) Haeger-Aronsen (1960)] and $0.6 \mathrm{mg} . / 100 \mathrm{ml}$. Only two had a PBG excretion in excess of $0.2 \mathrm{mg} . / 100 \mathrm{ml}$., 18 being within the range $0 \cdot 1-0 \cdot 2 \mathrm{mg} . / 100 \mathrm{ml}$. Haeger quotes $0.2 \mathrm{mg} . / 100 \mathrm{ml}$. as the upper limit of the normal range of PBG with a mean of $0.1 \mathrm{mg}$./ $100 \mathrm{ml}$. (Haeger, 1958; Haeger-Aronsen, 1960).

Of the workers 10 had a urinary lead concentration of $200 \mu \mathrm{g}$./litre or above. In all of these there was a raised ALA (above $0.6 \mathrm{mg} . / 100 \mathrm{ml}$.) and all but one had a raised coproporphyrin, above $150 \mu \mathrm{g}$./ litre, the one remaining being $148 \mu \mathrm{g}$./litre.

There were 24 cases in which the ALA was raised and the urinary lead was below $200 \mu \mathrm{g}$./litre, and 28 cases in which a raised coproporphyrin was associated with a normal urinary lead. In only two cases with a raised ALA was the coproporphyrin below $150 \mu \mathrm{g}$./litre. In eight cases with a coproporphyrin above $150 \mu \mathrm{g}$./litre the ALA was below $0.6 \mathrm{mg} . / 100 \mathrm{ml}$; ; in two of these it was 0.59 and $0.57 \mathrm{mg} . / 100 \mathrm{ml}$.

In 73 of the patients the punctate basophil count was below $1,000 / 10^{6}$ R.B.C. In 21 the count was in the range $1,000-3,000 / 10^{6}$ R.B.C., and in only six was the punctate count above $3,000 / 10^{6}$ R.B.C.

\section{Discussion}

Our results are in agreement with the general consensus of opinion that workers with exposure to lead have an increase in urinary ALA excretion. Our findings with regard to PBG seem not to corroborate the reports of those authors (Watson et al., 1953; Bashour, 1954, 1955) who found raised PBG excretions in lead-exposed workers, rather they conform with the findings of Waldenström (1937), Griggs and Harris (1958), and Haeger (1957, 1958), and Schwartz (personal communication), that the excretion of PBG in this group of workers is almost always normal. Tanabe's cases all had frank clinical plumbism, and it may well be that the excretion of PBG increases as the degree of lead absorption becomes such as to induce clinical symptoms. In any event, it seems not to rise to anything approaching the levels of ALA excretion.

In Fig. 1 the urinary levels of ALA in $\mathrm{mg} . / 100 \mathrm{ml}$. are plotted against those of urinary coproporphyrin in $\mu \mathrm{g}$./litre. From this it can be seen that the presence of any significant or linear correlation between the excretion of these two substances may be ruled out. Tanabe (1959) reported that the urinary coproporphyrin increased in parallel with the increase in ALA, and although our results show a general tendency for one to rise pari passu with the other, the wide scatter of points on the graph is sufficient to rule out any significant interrelation. It is possible that this is an indication that lead exerts an unequal influence on the enzyme systems responsible for the further metabolism of these two substances. 
TABLE 1

SEMIQUANTITATIVE AND QUANTITATIVE ESTIMATIONS OF COPROPORPHYRIN

\begin{tabular}{|c|c|c|c|c|c|c|}
\hline Semiquantitative & -- & \pm & + & ++ & $+t+$ & $++t+$ \\
\hline Numbers & 61 & 14 & 6 & 9 & 6 & 4 \\
\hline Mean ( $\mu \mathrm{g} . / 1)$. & 60 & 247 & 293 & 461 & 866 & 1,789 \\
\hline Range & $\begin{array}{r}14-176 \\
2 \text { above } 100\end{array}$ & $\begin{array}{r}74-397 \\
2 \text { below } 100 \\
2 \text { above } 300\end{array}$ & $\begin{array}{r}210-374 \\
4 \text { below } 300\end{array}$ & $\begin{array}{r}210-678 \\
2 \text { below } 400 \\
1 \text { above } 600\end{array}$ & $\begin{array}{r}516-1,131 \\
2 \text { above } 1,000\end{array}$ & $\begin{array}{r}1,057-2,279 \\
2 \text { below } 1,000\end{array}$ \\
\hline
\end{tabular}

On each patient the coproporphyrin was estimated in two ways, one of which was a simple semiquantitative method, and the other a fully quantitative one. The semiquantitative results were divided into five categories according to the degree of fluorescence observed under ultraviolet light, ,,,,,- \pm++++++++++ . The sets of results were compared to see whether the semiquantitative results fell within a definite range of the quantitative figures. The findings are set out in Table 1. It was hoped that by doing this it would be possible to forecast quantitative results from the very much simpler semiquantitative test. The means show that although some change in colour was detected between \pm and + , in fact it was pointless to make this differentiation. There was a considerable overlap in the range of all the groups; so much so that attempts to draw conclusions from these findings are of little value. It might be worth while, however, to extend this experiment so as to include 100 or 200 results in each group (our numbers of positives in each group were very small) and perhaps from these data valid conclusions might be drawn. It is hoped that further work in this direction will be attempted.

The majority (73) of our workers showed a punctate basophil count below $1,000 / 10^{6}$ R.B.C., and in the remaining 27 the presence of punctate basophils was in no way correlated with other findings. In the patient with the highest count $(12,300)$ the urinary lead was $64 \mu \mathrm{g}$./litre, the coproporphyrin was $37 \mu \mathrm{g}$./litre, and the ALA was $0.17 \mathrm{mg} . / 100 \mathrm{ml}$. We question the value of relying too heavily on the punctate basophil count to detect early lead absorption, and prefer to use it to supplement evidence supplied by earlier signs, e.g. coproporphyrin and ALA levels. The place of the punctate count has, however, been well established by Lane (1949).

Only four of the workers investigated had a haemoglobin below $90 \%$ and the findings in these four cases are set out in Table 2. Case 301, haemoglobin $84 \%$, had the highest punctate basophil count in the series $(12,300)$ although urinary lead, coproporphyrin, and ALA levels were well within normal limits. Case 426 (who had a haemoglobin of $84 \%$ ) had a raised ALA and coproporphyrin with a urinary lead of only $44 \mu \mathrm{g}$./litre and a punctate count below $3,000 / 10^{6}$ R.B.C. This worker has had nearly 30 years' exposure to lead, and these findings may possibly be due to the slow accumulation of lead over the years with subsequent effects on his haem metabolism. He showed no clinical signs or symptoms and felt very well when examined.

Figs. 2 and 3 show respectively the graphs obtained from plotting ALA and coproporphyrin against urinary lead. It was found from these that if the workers were divided into two groups, those with a urinary lead above and below $200 \mu \mathrm{g}$./litre, i.e. above and below the MAC quoted by Elkins (1950), then the levels of ALA and coproporphyrin in the group with the "normal" urinary lead were as high, if not higher, than in the group with the "high" urinary leads. The workers whose urinary leads were above $200 \mu \mathrm{g}$./litre had an accompanying increase in ALA and coproporphyrin. In 24 workers there was raised ALA excretion with a

TABLE 2

RESULTS IN FOUR WORKERS WITH HAEMOGLOBIN BELOW $90 \%$

\begin{tabular}{c|c|c|c|c|c}
\hline Case No. & Hb\% & $\begin{array}{c}\text { Urinary Lead } \\
(\mu \mathrm{g} . / 1 .)\end{array}$ & $\begin{array}{c}\text { Coproporphyrin } \\
(\mu \mathrm{g} . / \mathrm{l} .)\end{array}$ & $\begin{array}{c}\text { ALA } \\
(\mathrm{mg} / 100 \mathrm{ml} .)\end{array}$ & PBC/10 R.B.C. \\
\hline 301 & 84 & 64 & 37 & $0 \cdot 17$ & 12,300 \\
287 & 88 & 60 & 53 & $0 \cdot 28$ & Free \\
426 & 84 & 44 & 528 & $0 \cdot 78$ & 2,500 \\
384 & 88 & 76 & 69 & 0.53 & Free \\
\hline
\end{tabular}




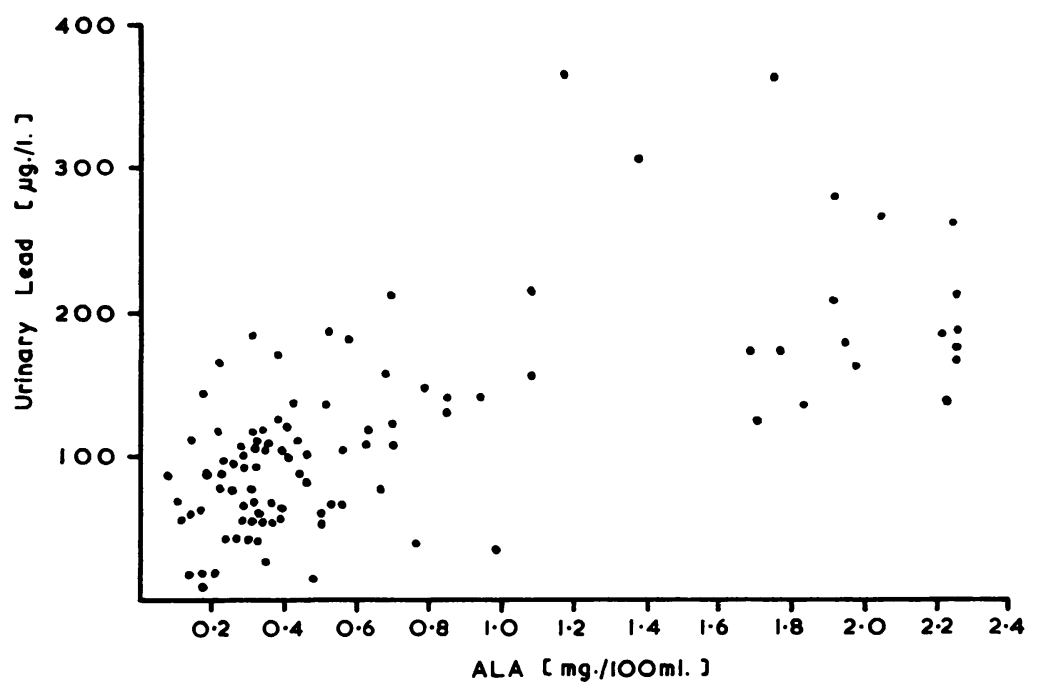

FIG. 2.-Urinary levels of ALA plotted against those of lead.

"normal" urinary lead, and in 28 workers a raised coproporphyrin excretion with a "normal" urinary lead.

The workers who showed evidence of altered metabolism of haem precursors may thus be divided into two groups: those with a raised urinary lead excretion, and those in whom the urinary lead is within normal limits.

It is interesting to speculate as to whether this latter group represents a class of individuals who have an abnormal susceptibility to the effects of lead, or who, if the exposure to lead increased, would be the first to demonstrate frank clinical plumbism.

Extended clinical and biochemical observation of workers who continue to be exposed to a lead hazard, and preferably of great magnitude, would be necessary before one can say whether or not

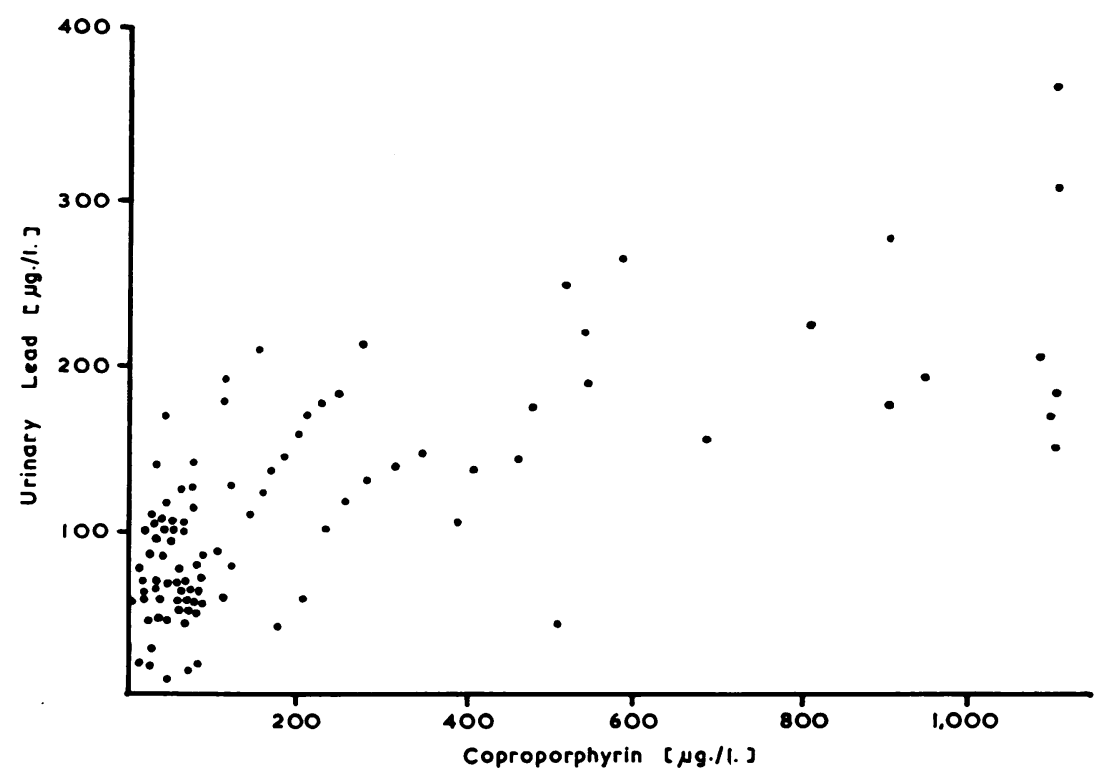

Fig. 3.-Urinary levels of coproporphyrin plotted against those of lead. 
there was any scientific basis for this impression, especially since the variability in the rate of lead excretion throughout the day may also influence these findings.

If this impression could be shown to be based on fact it might then be possible to identify susceptible subjects at an early stage.

This division into two groups with lack of correlation between urinary lead levels and those of urinary coproporphyrin is not in accord with the views of Marmet (1958) who found a highly significant correlation between the urinary coproporphyrin and lead excretions in 50 workers, and Haeger-Aronsen (1960) who similarly found a good correlation between these two and a highly significant relation between urinary ALA and lead excretion. King and Thompson (1961) found a quite distinct relation between the urinary coproporphyrin and lead excretion, although the coproporphyrin results were not quantitative.

Our thanks are due to Dr. A. R. Thompson, Professor R. E. Lane, and Mr. S. A. Roach for encouragement and advice. We should also like to thank the management of Vauxhall Motors for permission to publish this paper.

\section{REFERENCES}

Bashour, F. A. (1954). J. Lab. clin. Med., 44, 764.

(1955). Univ. Minn. med. Bull., 26, 423.

Biddle, D. A. (1936). Ind. Eng. Chem. Anal. Ed., 8, 99.

Elkins, H. B. (1950). The Chemistry of Industrial Toxicology. Wiley, New York

Griggs, R. C. and Harris, J. W. (1958). Clin. Res., 6, 188.

Haeger, B. (1957). Scand. J. clin. Lab. Invest., 9, 211

(1958). Lancet, 2, 606.

Haeger-Aronsen, B. (1960). Scand. J. clin. Lab. Invest., 12, Suppl. 47.

Holti, G., Rimington, C., Tate, B. C., and Thomas, G. (1958). Quart. J. Med. (n.s.), 27, 1 .

King, E., and Thompson, A. R. (1961). Ann. occup. Hyg., 3, 247.

Lane, R. E. (1949). Brit. J. industr. Med., 6, 125.

Marmet, J. (1958). Industrietoxikologische Untersuchungen be Bleirbeitern. Promotionsarbeit, No. 2674, Zurich.

Mauzerall, D., and Granick, S. (1956). J. biol. Chem., 219, 435.

Rimington, C. (1958). Broadsheet No. 21 (n.s.), Association of Clinical Pathologists.

(1960). Biochem. J., 75, 620.

, and Sveinsson, S. L. (1950). Scand. J. clin. Lab. Invest., 2 , 209.

Tanabe, Y. (1959). Jap. J. Nation's Hlth, 28, 386.

Tishkoff, G. H., Granville, N. B., Rosen, R., and Dameshek, W. (1958). Acta haemat. (Basel), 19, 321.

Waldenström, J. (1937). Acta med, scand., Suppl, 82.

Watson, C. J., Hawkinson, V., and Bossenmaier, II. (1953). Trans.

Watson, C. J., Hawkinson, V., and

With, T. K. Amer. (1955). Scand. J. clin. Lab. Invest., 7, 193.

Zondag, H. A., and van Kampen, E. J. (1956). Clin. chim. Acta, 1, 127. 